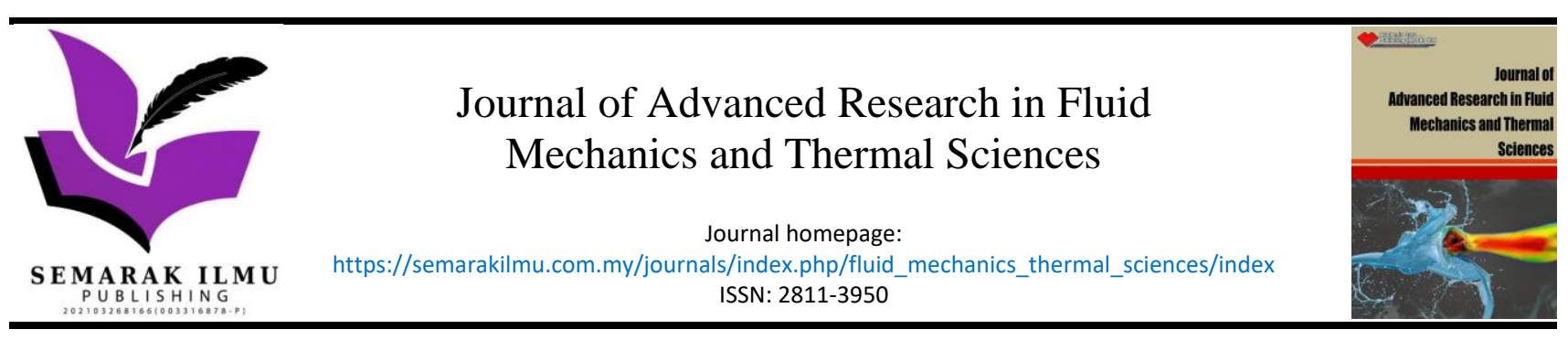

\title{
Preliminary Design of Mini Oil Refinery Plant
}

\author{
Renanto Handogo ${ }^{1,}{ }^{*}$, Fery Prasetyo ${ }^{1}$, Santi Puspita Sanjaya ${ }^{1}$, Annasit $^{1}$, Rendra Panca Anugraha $^{1}$ \\ Department of Chemical Engineering, Institut Teknologi Sepuluh Nopember, Kampus ITS Sukolilo 60111, Surabaya, Indonesia
}

\section{ARTICLE INFO}

Article history:

Received 10 October 2021

Received in revised form 11 December 2021

Accepted 20 December 2021

Available online 30 January 2022

\section{Keywords:}

Crude Distillation; Crude Oil; Economic; Feasibility; Mini Refinery

\section{ABSTRACT}

\begin{abstract}
As an archipelagic country, Indonesia faces challenges in supplying fuel to various regions. Some regions have small oil reserves and small fuel demand. Other regions have greater fuel demands. One solution to overcome the issue of fuel supply is to build and develop mini refineries with a scale of $6,000-20,000$ barrels per day to maximize the potential of existing oil reserves, reach remote areas, and meet domestic demands. This study aims to analyze the feasibility of a mini oil refinery from a technical and economic perspective. The feed used for this plant is light crude oil with API gravity 47.3002 from the Belida block, South Sumatra. The plant is designed with a capacity of 10,000 barrels per day to produce intermediate products. The production process at this plant uses a simple process to reduce capital costs, which consists of a Preheater, Pre-Flash Distillation Unit, Atmospheric Distillation Unit, and Vacuum Distillation Unit. From the results of economic analysis, the obtained capital cost of IDR 517,640 million and operational cost of IDR 2,860,622 million. Meanwhile, the payback period is 4.5 years, and the break-even point is $48 \%$. By considering the economic and technical aspects, this Mini Oil Refinery is feasible to be built.
\end{abstract}

\section{Introduction}

Growth in energy demand, especially fossil fuels, has continued to increase in recent decades. Indonesia's energy needs are still mostly met from fossil fuels such as oil and gas. Indonesia has several renewable energy potentials. However, the utilization of renewable energy is less than $2 \%$ per year. One of the abundant renewable energy sources is biomass, such as risk husks. Lubis (2018) has investigated the energy equivalent potential of risk husk. The study shows that the risk husk production in 2015 was able to produce energy equivalent to 5 million kiloliter gasoline. The processing of biomass into user-friendly energy products is still challenging. The renewable product prices are still less competitive than petroleum products. This makes refined petroleum products still promising for the next decades.

\footnotetext{
* Corresponding author

E-mail address: renanto@chem-eng.its.ac.id
}

https://doi.org/10.37934/arfmts.92.1.3950 
Indonesia has oil and gas reserves scattered on almost every island. Several oil and gas reserves in Indonesia have not been utilized properly due to unfavorable geographical conditions or the relatively small content of these sources. Oil and gas reserves in Indonesia are relatively large, reaching 2.5 billion standard barrel tanks (Bstb) and gas and associated gas reserves reaching 50 trillion standard cubic feet (Tcf) (Ministry of Energy and Mineral Resources, 2018). However, this is not supported by an adequate number of refineries.

The production of fuel from domestic refineries tends to decline so that it is unable to meet the increasing demand for fuels. It is due to inefficient refinery processing technology, and the cost of producing domestic fuels is more expensive than the price of imported fuel from Singapore (Risdiyanta, 2014). Oil production over the last ten years has shown a downward trend, from 346 million barrels ( 949 thousand BPD) in 2009 to around 283 million barrels ( 778 thousand BPD) in 2018 (Secretary-General Team of National Energy Council, 2019). The decline in production was due to the main oil-producing wells being closed, generally old, while the production of new wells is still relatively limited. Indonesia imports petroleum mainly from the Middle East so that its dependence on imports reaches around 35\% (Ministry of Energy and Mineral Resources, 2018).

According to the condition of oil resources in Indonesia, it is necessary to optimize the production of domestic refineries by increasing capacity and building new refineries. The Strategic Plan of the Ministry of Energy and Mineral Resources for 2020-2024 states plans to increase domestic fuel production by adding refinery capacity and exploring new refineries in Indonesia (Ministry of Energy and Mineral Resources, 2020). One of which is by accelerating the construction of mini oil refineries, with a production capacity of 6,000-20,000 barrels per day, especially in remote areas. The government plans to open mini-refinery investments in 8 clusters in Indonesia. The eight clusters that are the locations for the construction of the refinery are in the following areas: North Sumatra, the Long Strait of Malacca, Riau, Jambi, South Sumatra, South Kalimantan, North Kalimantan, and Maluku. The construction of the mini refinery is expected to solve the problems of the supply and distribution of crude oil and fuel in Indonesia.

The construction of a mini refinery has many advantages, such as a shorter design and construction time. In addition, it is more efficient and economical to build mini refineries in each oilproducing area than to build one large refinery, and oil from the area must be sent to refineries and can increase the marginal field economy (Chabibulloh et al., 2018). Therefore, a preliminary analysis of the development plan is needed to provide an overview of the technical and economic aspects of the mini-oil refinery project. In addition, this research is also expected to be a consideration and reference in further developing a mini oil refinery.

\section{Methodology}

\subsection{Design Base Data}

In this study, a case study is used as the basis for raw materials, namely using crude oil from one of the fields representing the South Sumatra cluster, namely crude oil from the Belida block. The specifications for the crude oil are given in Table 1, 2 and 3 as follows: 
Table 1

Crude oil specification

\begin{tabular}{ll}
\hline Density $\left(\mathrm{kg} / \mathrm{m}^{3}\right)$ & 790.542 \\
Molecular Weight & 180.08 \\
API & 47.3002 \\
Sulphur Content (\%wt) & 0.024 \\
Pour Point $\left({ }^{\circ} \mathrm{C}\right)$ & 19.002 \\
Specific Gravity (water $=1)$ & 646.7716 \\
Watson UOP K-factor & 12.14 \\
\hline
\end{tabular}

\begin{tabular}{|c|c|}
\hline TBP Distillation, Liquid Volume\% & Temperature, ${ }^{\circ} \mathrm{C}$ \\
\hline 0 & -95.10 \\
\hline 5 & 52.12 \\
\hline 10 & 78.28 \\
\hline 30 & 153.59 \\
\hline 50 & 227.16 \\
\hline 70 & 319.08 \\
\hline 90 & 490.68 \\
\hline 95 & 581.94 \\
\hline 100 & 830.47 \\
\hline
\end{tabular}

Table 3

\begin{tabular}{ll}
\multicolumn{2}{l}{ Light-ends component } \\
\hline Component & \%Mass \\
\hline Methane & 0 \\
Ethane & 0.004 \\
Propane & 0.091 \\
Isobutane & 0.555 \\
n-butane & 0.521 \\
Isopentane & 0.893 \\
n-pentane & 0.396 \\
\hline
\end{tabular}

From the crude oil assay data, in this study, calculations were carried out through simulation with Aspen HYSYS V11 software. This plant is designed to operate continuously 24 hours for 330 days per year with a production capacity of 10,000 barrels per day of crude oil.

\subsection{Design Procedure}

\subsubsection{Steady state modelling}

The earliest procedure for crude oil distillation unit design used a mass balance and energy. Process flowsheets as well as mass and energy balance calculations will be carried out using Aspen HYSYS software. In the steady-state simulation, a proper fluid package should be selected to obtain a suitable simulation model in the actual condition. Many fluid packages are available in the Aspen HYSYS software. In this study, process simulation about the Mini Oil Refinery Plant uses PengRobinson (PR) state equation. 


\subsubsection{Feasibility analysis}

The purpose of this study is to analyze the feasibility of a mini oil refinery from a technical and economic perspective. The analysis carried out to obtain conclusions is as follows: an analysis of the technical aspects. In principle, technical analysis is an essential step. This analysis is to study the plant element related to the design, specifications, technology level, and equipment (Shaallan, 2012). The technical aspects of this plant in terms of production technology or production processes are used under the characteristics of raw materials, namely crude oil. In addition, the technical aspects also include the capacity of the designed plant and the types of products produced at this mini refinery.

Second, economic analysis is one of the parameters of whether a plant is feasible or not. On a determined basis, a plant economically requires the number of raw materials needed and products produced from the plant based on the mass balance that has been calculated on technical aspect. In addition, it is necessary to consider the equipment for the process based on the specifications of the required equipment as calculated based on the mass and energy balance. It is also necessary to analyze the costs required for the plant to operate and utilities. The economic aspects will be considered using several economic feasibility parameters such as Net Present Value (NPV), Internal Rate of Return (IRR), Pay Out Time (POT), and Break-Even Point (BEP) (Shaallan, 2012). The cost of constructing a mini oil refinery consists of capital costs and operating costs. The payment method of the capital cost is calculated using linear depreciation over several years of production.

\subsection{Process Selection and Description}

Crude oil produced from the field has a relatively low selling price because it can rarely be used directly. Therefore, it is necessary to refine crude oil into the desired products. Oil refineries play an essential role in the process. There are refinery configurations from the simplest to the most complex in sequence, are topping refinery, hydro skimming refinery, cracking, and full conversion [21].

In contrast to large oil refineries, which have complex processes up to conversion processes, mini refineries are mostly by separation or distillation processes. For a small-scale oil refinery, it is considered more profitable if the process used is simple and does not require large capital costs. Therefore, the topping refinery configuration type is considered the most profitable.

Topping refinery is the simplest refinery configuration. In this type of configuration, it generally consists of an atmospheric distillation unit that produces products in the form of light ends $\left(\mathrm{C}_{1}-\mathrm{C}_{4}\right)$, naphtha, kerosene, and diesel. The resulting atmospheric residue is generally sold as fuel oil or as an intermediate product [21]. In addition, oil refineries with this type of configuration also have a Vacuum Distillation Unit (VDU)) and supporting basic operations (The International Council On Clean Transportation, 2011).

Typical products from crude oil distillation systems are LPG, light naphtha, heavy naphtha, kerosene, diesel, atmospheric gas oil (AGO), light vacuum gas oil (LVGO), heavy vacuum gas oil (HVGO), and vacuum residue (VR). A typical crude oil distillation consists of a preheat train, flash unit or pre-fractionator, an atmospheric distillation unit, and a vacuum distillation unit (Wang et al., 2016). At this plant, we design the crude oil distillation process according to this configuration with four main unit processes.

Topping refinery looks the most suitable configuration for the small-scale oil refinery. The resulting products are categorized as intermediate products, where the revenue is relatively small. The refinery cost should be minimized to achieve the design economy. The costs of several types of refinery equipment, such as heat exchanger and pipeline, can be minimized by improving the geometrical design and optimizing the pipeline route to obtain a more compact design. Gunawan et 
al., (2020) use Djikstra's algorithm to optimize the pipeline design by considering several mechanical constraints.

\subsubsection{Preheater}

The crude oil is stored in a tank with operating conditions at $30^{\circ} \mathrm{C}$ and at atmospheric pressure. Then, the crude oil will be pumped to the heat exchanger. This preheater unit implements heat integration or a heat exchanger network. The crude oil distillation process is a process that uses a large amount of energy. As reported that the energy consumed throughout the refinery process is comparable to $7 \%$ to $15 \%$ of refined crude oil, of which $35 \%$ to $45 \%$ is consumed by atmospheric distillation units and vacuum distillation units (Szklo and Schaeffer, 2007).

Heat integration is crucial for the energy efficiency of the crude oil distillation process operation. Heat integration is achieved by exchanging heat between the hot process stream and the cold process stream (Ochoa-Estopier and Jobson, 2015). The heat integration in this plant is achieved by exchanging the heat stream from the product of the atmospheric distillation column, such as kerosene, diesel, and AGO as the heating medium for crude oil. The typical configuration of crude oil preheater is given in Figure 1. The figure shows the preheating train 1, where the crude oil is heated before entering the desalter.

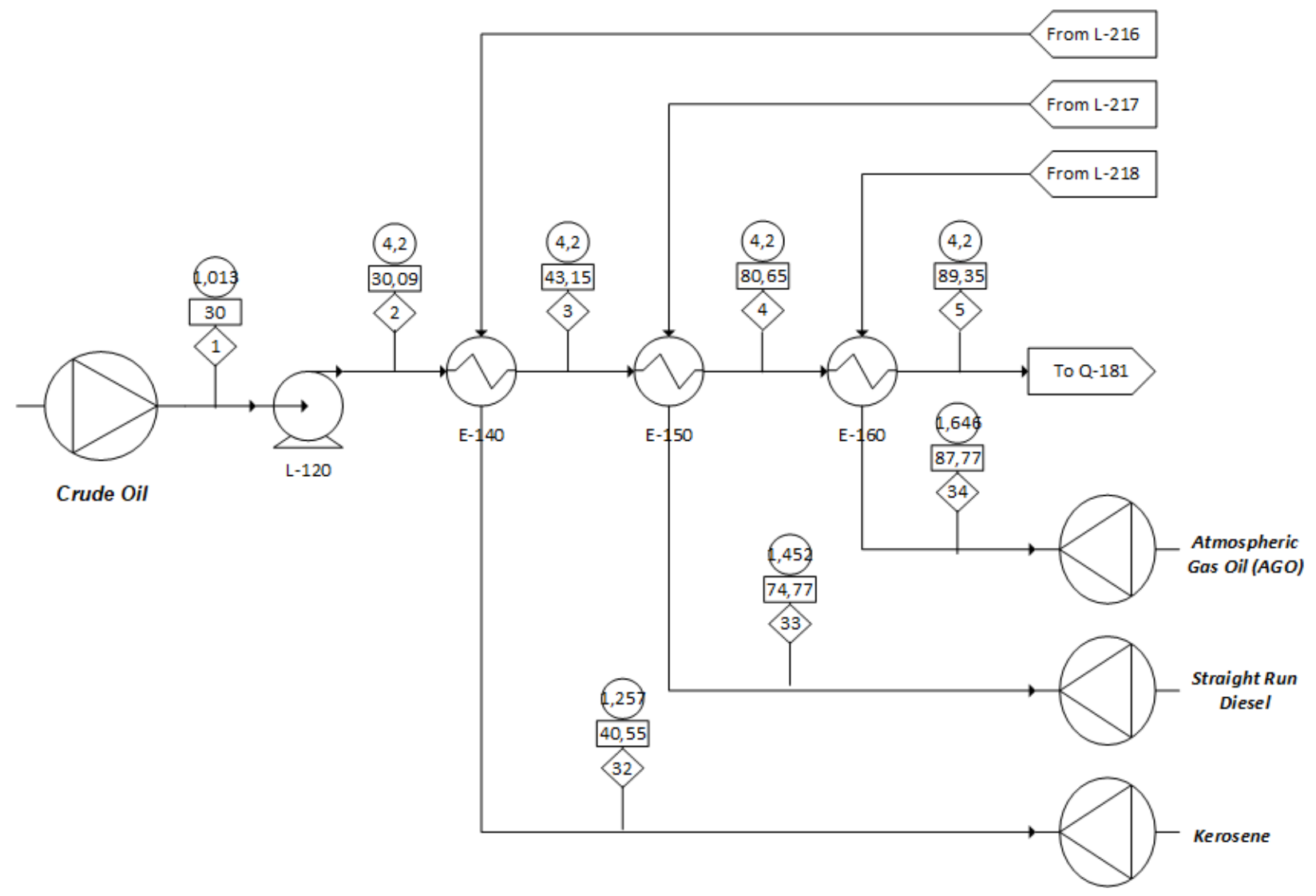

Fig. 1. Crude oil preheater

In a small-scale oil refinery, the equipment is designed compactly and in modular form for easy installation. Improving the design parameters of the heat exchanger will increase the thermal efficiency and makes the design more compact which in turn reduces operating costs (Khata et al., 2020). One of the design parameters that affect the heat transfer performance is the baffle spacing. 
The heat transfer coefficient in the shell side of the heat exchanger decreases gradually with increasing baffle spacing [14].

\subsubsection{Pre-flash distillation unit}

After the crude oil has been processed in the preheater unit, the crude oil that comes out will be heated in a pre-flash furnace to a temperature of $275^{\circ} \mathrm{C}$ at a pressure of 4.2 bar. Crude oil that comes out of the furnace is already in a saturated state. Crude oil will undergo partial evaporation in which there are two phases, namely the vapor phase and the liquid phase. After that, the crude oil will go to the pre-flash distillation column. The existence of this pre-flash distillation column serves to separate the light fractions of crude oil, namely light-ends and light naphtha. This pre-fractionation column is also used to reduce the load on the crude distillation unit and reduce the energy $[6,9]$.

The configuration of pre-flash column is given in Figure 2. The pre-flash column consists of 16 trays with feed entering the $16^{\text {th }}$ tray. In addition, the heating medium uses open steam which is injected from the bottom of the column. In the furnace, crude oil will experience maximum heating with an optimal temperature of $260-300^{\circ} \mathrm{C}$. It aims to achieve the optimum temperature of the fractionation column so that the liquid and vapor phases will be separated properly. The higher the furnace temperature, the higher the total product produced. However, the higher the furnace temperature, the higher the total operating costs [5].

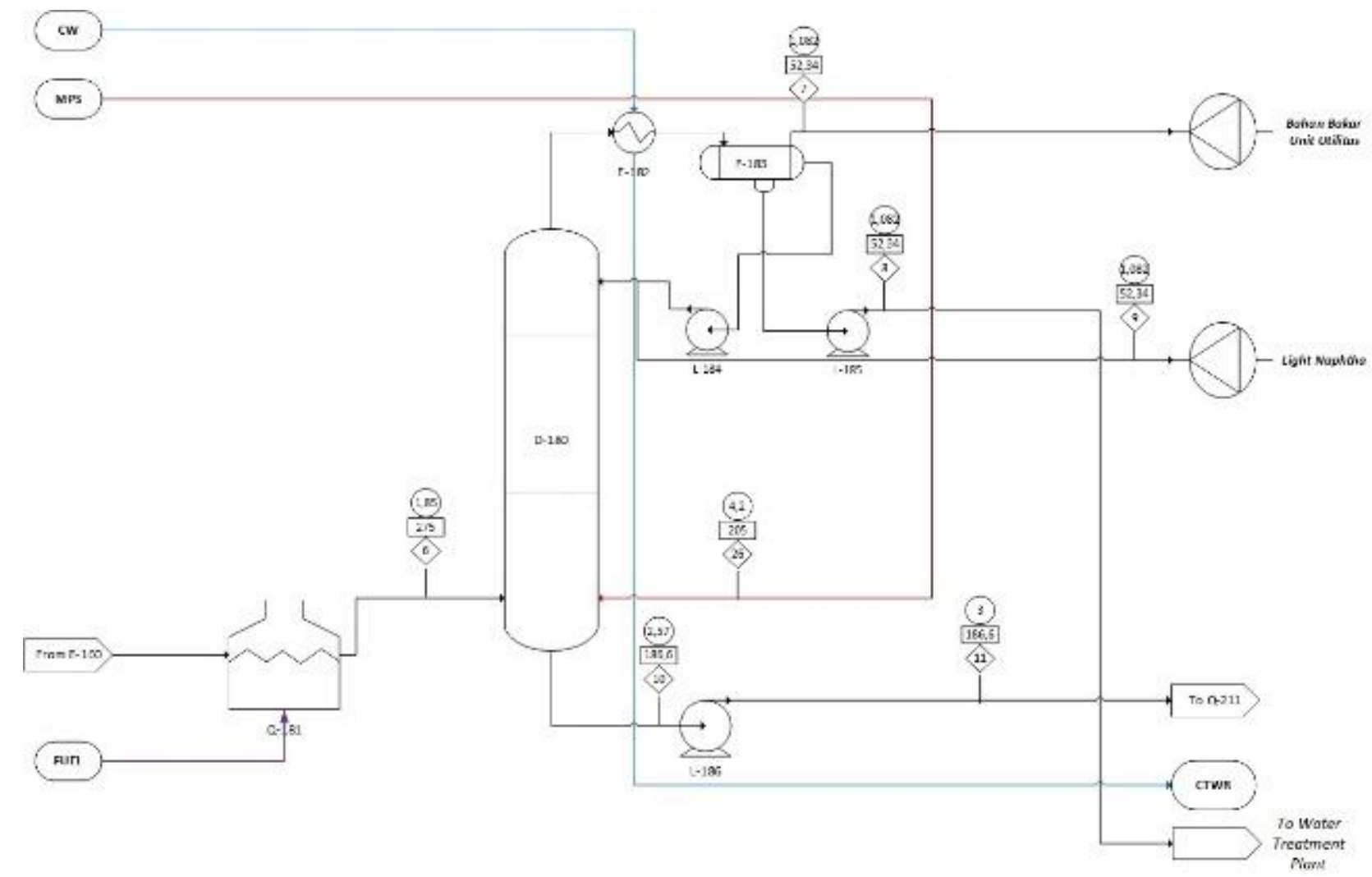

Fig. 2. Pre-flash distillation unit

\subsubsection{Atmospheric distillation unit}

The bottom product from the pre-flash column will enter the furnace. ADU Furnace operates at a pressure of 1.85 bar and a temperature of $340^{\circ} \mathrm{C}$. From the furnace then it flows into a distillation column or an Atmospheric Distillation column. This atmospheric distillation column consists of a main 
fractionating column and three stripper columns. In this fractionation column, crude oil will separate into atmospheric residue at the bottom, the top product of this column is heavy naphtha while the existing side streams are AGO (atmospheric gas oil), diesel, and kerosene. In this fractionation column, there is also a pump around process which is the process of taking some of the liquid from the column from a saturated state then cooled to sub-cooled and returned to the column [9]. This aims to condense the fraction that should not evaporate. This atmospheric distillation column consists of 40 trays and the feed enters the 36th tray from the top of the column. The heating medium used is also the same as the pre-flash column, namely open steam which is injected from the bottom of the column. The configuration of atmospheric distillation unit is given in Figure 3.

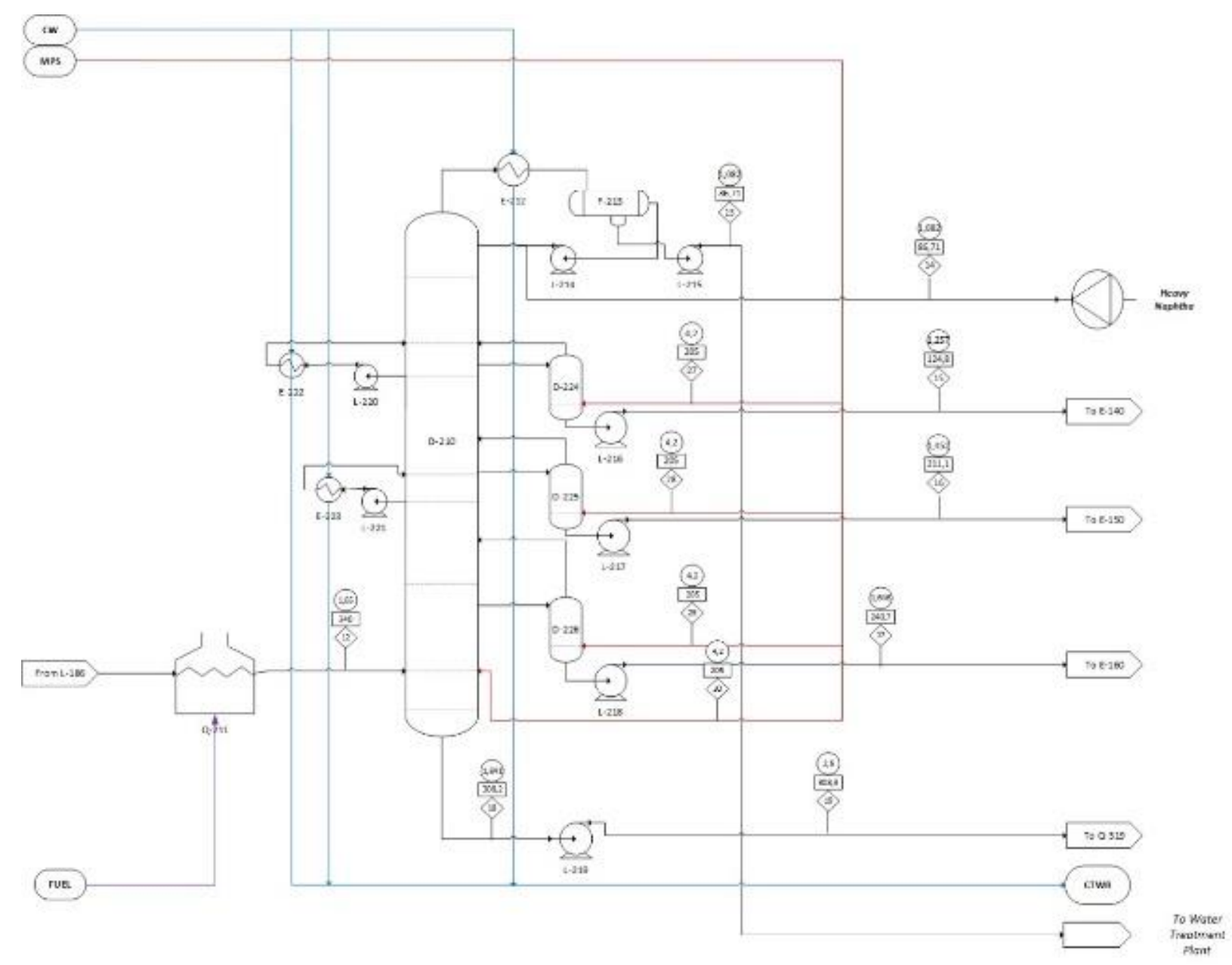

Fig. 3. Atmospheric distillation unit

\subsubsection{Vacuum distillation unit}

Atmospheric residue from the atmospheric distillation unit will be pumped by the VDU Feed Pump to the furnace. The VDU Furnace operates at a pressure of 0.16 bar and a temperature of $405^{\circ} \mathrm{C}$. Out of the furnace, the atmospheric residue will enter the vacuum distillation column. This vacuum distillation unit functions is to separate atmospheric residue from the ADU unit based on differences in boiling points or to recover gas oil [9]. The principle of operation of this unit is the distillation process under vacuum because a decrease in pressure will cause a decrease in the boiling point so that the separation process can be carried out without thermal cracking $[3,10]$. The configuration of vacuum distillation unit is given in Figure 4. 


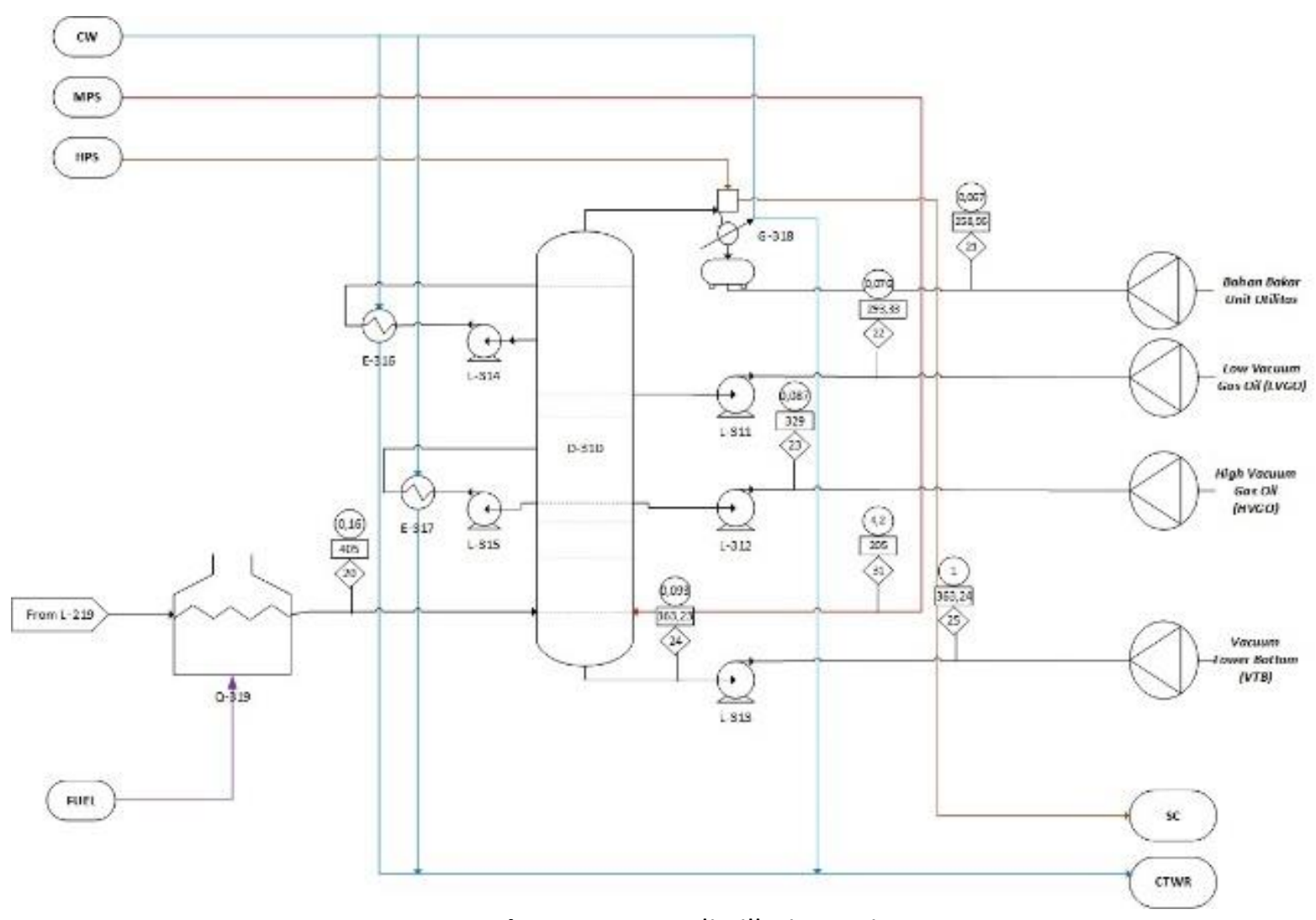

Fig. 4. Vacuum distillation unit

Vacuum conditions were obtained by drawing the product gas at the top of the column using a two-stage steam ejector which was arranged in series. The steam used in this steam ejector is high pressure steam with a steam pressure of up to $10 \mathrm{psig}$. The separation process takes place at a pressure of $50-70 \mathrm{mmHg}$ and a temperature of $405^{\circ} \mathrm{C}$. The vacuum distillation column consists of 10 trays and the feed enters at the bottom of the column. In this unit, the heater used is in the form of open steam which is injected at the bottom of the column.

\section{Results and Discussion}

This section presents and discusses the simulation and evaluation results of the mini oil refinery. The results include product analysis and economic analysis.

\subsection{Refinery Product Analysis}

In this study, plant production calculations such as mass and energy balances are performed by simulation using Aspen HYSYS software. The simulated process is like the description of the process described previously, including preheater, pre-flash distillation, atmospheric distillation, and vacuum distillation. This technical analysis considers the specified production process, operating conditions, and production can take place well.

Based on the mass balance calculations that have been carried out on the preliminary design of the Mini Oil Refinery factory with the assumption that the factory operates 24 hours for 330 days per year, the factory requires or processes raw materials in the form of crude oil as much as 10,000 barrels per day or 3,300,000 barrels per year. This factory produces several products which are intermediate products as shown in Table 4. 
Table 4

Mini oil refinery plant products

\begin{tabular}{lll}
\hline Product & Boiling Range $\left({ }^{\circ} \mathrm{C}\right)$ & Production $(\mathrm{kg} / \mathrm{h})$ \\
\hline Off Gas & IBP -15 & 665.4 \\
Light Naphtha & $15-80$ & 3756 \\
Heavy Naphtha & $80-175$ & 12700 \\
Kerosene & $175-230$ & 7432 \\
Diesel & $230-340$ & 12650 \\
Atmospheric Gas Oil (AGO) & $340-370$ & 2567 \\
Light Vacuum Gas Oil & $370-510$ & 1576 \\
Heavy Vacuum Gas Oil & $510-550$ & 287.1 \\
Vacuum Tower Bottom & $550-$ FBP & 4580 \\
\hline
\end{tabular}

From the simulation results shown in Table 4, most products from this oil refinery are heavy naphtha and diesel. The product from this mini oil refinery is an intermediate product or not a final product. These products still require reprocessing to become the final product. The profit margin obtained from this intermediate product is indeed not as much as the profit from the final product. However, to produce the final product requires additional, more complex processes that will increase the cost of capital, equipment, and utilities required. Therefore, it does not fully fit into the scheme of small-scale oil refineries.

All products in this factory will be sold as intermediate products, except off-gas products. The gas produced will be used as a utility, namely as furnace fuel. Of course, this will reduce the cost of expenditure for utilities which is quite large, because the furnace load both pre-flash furnace, ADU furnace, and VDU furnace from the simulation results obtained is very high and requires high fuel as well. The pre-flash furnace load itself has been reduced by the integration of heat in the crude preheater unit. The heat integration is proven to be able to reduce the burden on the utility of the fuel used as well as the use of energy in the atmospheric and vacuum distillation column [13].

\subsection{Economic Analysis}

In the oil refinery project, economic analysis is one of the parameters of whether a factory is feasible or not. The economic aspects will be considered using several economic feasibility parameters such as Net Present Value (NPV), Internal Rate of Return (IRR), Pay Out Time (POT), and Break-Even Point (BEP) (Shaallan, 2012). Cash inflow is derived from the proceeds from sale of product from the refinery. Cash Outflow (expenses incurred) consists of the cost of constructing a mini oil refinery consists of capital costs and operating costs, purchases of raw materials, taxes to be paid on the based on agreed contacts (Erfando and Herawati, 2017).

Economic analysis is carried out using the discounted cash flow method whose value is projected in the present. Products of this plant are light naphtha, heavy naphtha, kerosene, diesel, AGO, LVGO, HVGO, and VTB and the estimation product selling price of IDR 3,242,402,437,820/year.

Table 5 shows the amount of capital costs. The amount of CAPEX is equal to the amount of TCI (Total Capital Investment) without considering the cost of workers in the construction of the factory, so the value of CAPEX is the same as the value of $\mathrm{FCl}$ (Fixed Investment). Through the calculation of the parameters above, the CAPEX value of IDR 517,640,918,579.75.

Table 6 shows the amount of operational costs of this plant. The manufacturing costs of this plant is IDR $2,517,347,560,097.27$ and the general expenses is $343,274,667,285.99$. Operating costs consisting of purchasing electricity, water, chemicals, labor, supply management needed per day, administration cost, research, and development cost. In this mini oil refinery plant, the gas as fuel come from off-gas produced in this plant. The life of the plant is estimated at 10 years with a 
depreciation of $10 \%$ per year. OPEX (Operational Expenditure) is derived into manufacturing costs and general expenses. So that the total operational costs are IDR 2,860,622,227,383.

Table 5

Capital costs

\begin{tabular}{ll}
\hline Fixed capital investment & IDR 517,640,918,579.75 \\
\hline Working capital investment & IDR 129,410,229,644.94 \\
\hline Total capital investment & IDR 647,051,148,224.69 \\
\hline
\end{tabular}

Table 6

Operating costs

Manufacturing costs

Direct production cost (raw material,

maintenance, labor, utility, $\quad$ IDR 2,283,211,647,058.06

laboratory)

Fixed charge (Depreciation, taxes,

insurance, loan)

Plant overhead cost

IDR 91,104,801,670.04

General expenses

Product distribution and sales costs IDR 143,031,111,369.16

Administration costs

IDR $57,212,444,547.67$

Research and development costs IDR 143.031.111.369,16

Table 7 shows the result of economic analysis. Net Present Value is an analysis that compares the investment value present, with the investment value in the future. The NPV value is IDR $737,737,269,026$ where the NPV is positive (NPV > 0), indicating that the projected income generated or invested exceeds the projected costs incurred. So, this plant is feasible to be built.

\section{Table 7}

Economic analysis parameters

\begin{tabular}{ll}
\hline NPV & IDR 737,737,269,026 \\
\hline IRR & $31 \%$ \\
\hline POT & 4.51 years \\
\hline BEP & $48 \%$ \\
\hline
\end{tabular}

Internal Rate of Return based on discounted cash flow is a certain interest rate at which all receipts will exactly cover all capital expenditures. IRR is the value of the discounted rate causing the difference in present value (NPV) to be 0 . Discounted rate is a value that expresses changes in the value of the value in the future. The IRR value is $31 \%$. The IRR value obtained is greater than the loan interest, which is $8 \%$ per year. The IRR value of $31 \%$ obtained from the calculation shows that this plant is feasible to be built with the bank loan interest rate of $8 \%$ per year [15].

Pay out time, which is the time when the capital returns through accumulative cash flow. Pay out time is the time to return the investment capital from the sale of products that make a profit. It was found that the payback period is 4.51 years. This shows that this plant is feasible to build because the POT obtained is less than the estimated age of the plant.

Break-even point analysis is used to determine the amount of production capacity where the total production costs are the same as sales results. Fixed costs, variable costs, semi variable costs, and total costs are not affected by production capacity. The fixed costs include depreciation, taxes, insurance, loan. The variable costs include raw material, utility, and royalty. The semi variable costs include labor, maintenance, laboratory, general expenses, and plant overhead cost. From the 
calculation, the break-even point is $48 \%$, means that the production capacity when expenditure is exactly equal to the value of sales, namely when production is $48 \%$ of full capacity.

\section{Conclusions}

Based on the study, it can be concluded that technically, a Mini Oil Refinery Plant with a capacity of 10,000 barrels of crude oil per day is feasible to be applied in a certain region of Indonesia. The raw material used in this study is crude oil from the Belida block. The plant operates continuously 24 hours/day for 330 days a year. The life of the plant is 10 years with a construction period of 2 years. Products of this plant are light naphtha, heavy naphtha, kerosene, diesel, AGO, LVGO, HVGO, and VTB. Economically, this Mini Oil Refinery Plant has a fixed capital investment of IDR $517,640,918,579.75$, working capital investment of IDR 129,410,229,644.94, total capital investment of IDR 647,051,148,224.69, and a product selling price of IDR 3,242,402,437,820/year. After calculating and analyzing these aspects, the Mini Oil Refinery has an Internal Rate of Return of 31\%, which is above the bank loan interest rate of $8 \%$ per year. The Pay Out Time is 4.51 years and the break-even point is at $48 \%$ of full capacity. Based on these considerations, the Mini Oil Refinery plant is feasible to be built.

\section{Acknowledgement}

This work was supported by a research grant from a Research and Technology Ministry/National Research and Innovation Agency Republic of Indonesia through PDUPT project under contract No. 3/E1/KP.PTNBH/2021.

\section{References}

[1] Chabibulloh, Bilal, Wisnu Kusuma Atmaja, Juwari Purwo Sutikno, and Renanto Handogo. "Pra Desain Pabrik Produksi Gasoline pada Kilang Minyak Skala Kecil." Jurnal Teknik ITS 7, no. 1 (2018): F127-F131. https://doi.org/10.12962/i23373539.v7i1.28915

[2] Erfando, Tomi, and Ira Herawati. "Analysis of Petroleum Downstream Industry Potential in Riau Province." Journal of Geoscience, Engineering, Environment, and Technology 2, no. 2 (2017): $178-182$. https://doi.org/10.24273/jgeet.2017.2.2.304

[3] Fahim, M. A., T. A. Alsahhaf, and A. Elkilani. "Chapter 2-Refinery feedstocks and products." Fundamentals of petroleum refining (2010): 11-31. https://doi.org/10.1016/B978-0-444-52785-1.00002-4

[4] Gunawan, Gunawan, Yanuar Yanuar, A. S. A. Utomo, and F. Fariz. "Reduction of Drag Resistance by Pressure Drop in Pipeline with 3-Dimensional Design Optimization." Journal of Advanced Research in Experimental Fluid Mechanics and Heat Transfer 1, no. 1 (2020): 1-10.

[5] Handogo, Renanto. "Optimization on the performance of crude distillation unit (CDU)." Asia-Pacific Journal of Chemical Engineering 7 (2012): S78-S87.https://doi.org/10.1002/apj.644

[6] Ji, Shuncheng, and Miguel Bagajewicz. "Design of crude distillation plants with vacuum units. I. Targeting." Industrial \& engineering chemistry research 41, no. $24 \quad$ (2002): 6094-6099. https://doi.org/10.1021/ie011040u

[7] Kadim, Zena Khalefa, and Kamil Abdulhussein Khalaf. "Numerical study of heat transfer enhancement in contour corrugated channel using water and engine oil." CFD Letters 12, no. 12 (2020): 17-37. https://doi.org/10.37934/cfdl.12.12.1737

[8] Lubis, Hamzah. "Renewable Energy of Rice Husk for Reducing Fossil Energy in Indonesia." Journal of Advanced Research in Applied Sciences and Engineering Technology 11, no. 1 (2018): 17-22.

[9] Luyben, William L. "Distillation Design and Control Using Aspen Simulation" John Wiley \& Sons, Inc (2006). https://doi.org/10.1002/0471785253

[10] Maples, Robert E. "Petroleum Refinery Process Economics. 2nd." Pet. Sci. 491 (2000).

[11] Ministry of Energy and Mineral Resources, 2018. Handbook of Energy and Economic Statistics of Indonesia 2018. Handb. Energy Econ. Stat. Indones. 129.

[12] Ministry of Energy and Mineral Resources, 2020. Peraturan Menteri Energi dan Sumber Daya Mineral Republik Indonesia Nomor 16 Tahun 2020 Tentang Rencana Strategis Kementerian Energi Dan Sumber Daya Mineral Tahun 
2020-2024.

[13] Ochoa-Estopier, Lluvia M., and Megan Jobson. "Optimization of heat-integrated crude oil distillation systems. Part I: The distillation model." Industrial \& Engineering Chemistry Research 54, no. 18 (2015): 4988-5000. https://doi.org/10.1021/ie503802j

[14] Omar, Hossin, Suliman Alfarawi, Azeldin El-sawi, and Hassan Alobeidy. "Study the Effect of Baffle Spacing on Heat Transfer and Pressure Drop in Shell and Tube Heat Exchanger." Journal of Advanced Research in Numerical Heat Transfer 6, no. 1 (2021): 22-30.

[15] Peters, Max Stone, Klaus D. Timmerhaus, and Ronald Emmett West. Plant design and economics for chemical engineers. Vol. 4. New York: McGraw-Hill, 2003.

[16] Risdiyanta, 2014. Mengenal Kilang Pengolahan Minyak Bumi ( Refinery ) Di Indonesia. Forum Teknol. 05, 46-54.

[17] Secretary General Team of National Energy Council, 2019. Indonesia Energy Out Look 2019.

[18] Shaallan, H.Y., 2012. Economic Feasibility Study for Petroleum Projects. J. Pet. Res. Stud. $26-47$. https://doi.org/10.52716/iprs.v3i1.62

[19] Szklo, Alexandre, and Roberto Schaeffer. "Fuel specification, energy consumption and CO2 emission in oil refineries." Energy 32, no. 7 (2007): 1075-1092. https://doi.org/10.1016/i.energy.2006.08.008

[20] The International Council On Clean Transportation, 2011. An Introduction To Petroleum Refining and the Production of Ultra Low Sulfur Gasoline. Energy Econ. Appl. Optim. 1-38.

[21] Treese, S. A., P. R. Pujadó, and D. S. J. Jones. "Handbook of petroleum processing, ed." SpringerReference, Cham (2015). https://doi.org/10.1007/978-3-319-14529-7

[22] Wang, Ziyuan, Qiang Xu, and Thomas Ho. "Optimal retrofit design of crude distillation units for processing shale gas/natural gas condensate oil." Chemical Engineering \& Technology 39, no. 6 (2016): 1099-1110. https://doi.org/10.1002/ceat.201500227 